\title{
Om at tilskrive sig Troens rare klenodie
}

\author{
Af Niels Egebak
}

I. Litteraturhistorien er en institution, hvis ressort er de »litteraturhistoriske sandheder «. Som enhver institution vogter den (eller dens funktionærer: litteraturhistorikerne, universitetets filologiske instituter) nidkært over dette ressort og disse sandheder, kodificeret og bogført i massen af litteraturhistoriske skrifter.

Hvad litteraturhistoriens funktionærer ofte nødigt indrømmer (om de gør sig det klart er en anden sag) er at disse institutionaliserede sandheder ikke er faldet ned fra himlen, men er resultater af bestemte loesemåder, og at ingen læsemåde $\mathrm{i}$ og for sig kan hævdes at være den rette. At de omtalte sandheder med andre ord så langt fra at være sandheder tværtimod er videns- eller kundskabseffekter, produceret gennem videnskabeligt arbejde og derefter sat i omløb under varebetegnelsen sandheder, og at de derfor også til enhver tid kan underkastes kritik, revision eller modifikation, eventuelt optages som integrerende del af en mere omfattende kundskabseffekt.

I.2. Den læsning af Grundtvigs kendte salme »Hil dig Frelser og Forsoner«, der her vil blive forsøgt, fremlægges derfor heller ikke som en ny litteraturhistorisk sandhed. Der er blot tale om et forsøg på at læse denne salme på en ny måde og således måske producere en ny viden om den, som kan lægges ud til diskussion. Som enhver anden læsning - men i dette tilfælde sker det bevidst og eksplicit - er også denne bestemt af læseren og læsersituationen. Det vil her sige, at teksten ikke læses - eller ikke i første række læses - som et historisk dokument, hverken om Grundtvig eller om Grundtvigs kristendomsopfattelse, men som en tekst »her og nu«, som var den »trykt i dette år«, og som en integrerende del af den tekstmasse, der udgør vor samtid eller vor samtidighed.

At den er en del af denne tekstmasse og som sådan i besiddelse af 
samme aktualitet som en hvilken som helst nutidig tekst, fremgår alene af den kendsgerning, at den - ganske vist $\mathrm{i}$ en modificeret form, der ikke er uden enhver interesse - er optaget i den salmebog, som hver søndag tages i brug i den danske folkekirke. Men iøvrigt indgår det i den omtalte læsersituation (altså nærværende læsers litteraturforståelse), at enhver tekst, uanset dens produktionstidspunkt, bliver betragtet som nærværende og samtidig, og derfor også bliver læst i lyset af den litterære tilstand netop nu.

Dette er muligvis diskutabelt. Men det vil ikke blive diskuteret her, bl. a. fordi det er den egentlige energikilde til produktionen af den videnseffekt, der her fremlægges uden at hypostaseres til litteraturhistorisk sandhed. Iøvrigt er den omtalte betragtningsmåde i fuld overensstemmelse med et alment anerkendt traditionsbegreb, formuleret af T. S. Eliot, som et sted har hævdet, at traditionen med nødvendighed må modificeres for hvert nyt værk, der bliver til, hvis den i stedet for at gå til grunde skal kunne optage det nye i sig (»Tradition and the individual talent $\ll)$. I dette perspektiv bliver det - hvis en retfærdiggørelse ellers skulle være påkrævet - fuldt berettiget at læse Grundtvigs tekst på samme måde, som man læser en nutidig tekst.

I.

Hil dig, Frelser og Forsoner! Verden Dig med Torne kroner, Du det seer, jeg har isinde Rosen-Krands om Kors at vinde, Giv dertil mig Mod og Held!

2.

For Dit Ansigt vil jeg træde, Thi jeg troer, Du er tilstæde; Jeg tilbeder Dig i Støvet, Fordi reen, som Guldet prøvet, Du er dog miskundelig!

3.

I Dit røde Hav jeg havner, Dine Fødder jeg omfavner, Thi ei stolt Du mig foragter, Mig fra Korsets Træ betragter Du med dyb Medlidenhed!
4 .

Ak, hvor fattig! ak hvor nøgen!

Gruelig er med Dig Spøgen!

Men jeg veed, for det at lide,

Født Du blev ved Midnats-Tide,

Selv Du valgde Korsets Skam!

5 .

Hvad har Dig hos Gud bedrøvet?

Og hvad elsked Du hos Støvet,

At $\mathrm{Du}$ vilde Alt opgive,

For at holde os ilive,

Os Dig at meddele heel?

6.

Kiærligheden, Hjerte-Gløden, Stærkere var her end Døden, Heller giver Du end tager, Ene derfor Dig behager Korsets Død i vores Sted! 
7.

Ak! nu føler jeg tilfulde

Hjertets Haardhed, Hjertets Kulde!

Hvad udsprang af disse Fjelde,

Navnet værdt, til at giengælde

Frelser-Mand, din Kiærlighed?

8.

Dog jeg troer, af dine Vunder Væld udsprang til stort Vidunder, Mægtigt til hver Steen at vælte, Til Iis-Bjerge selv at smelte, Til at tvætte Hjertet reent!

9.

Derfor beder jeg med Taarer:

Leed den ind i mine Aarer,

Floden, som kan Klipper vælte, Floden, som kan Iis-Bjerg smelte, Som kan Blod-Skyld tvætte af!
IO.

Du, som har Dig selv mig givet,

Lad i Dig mig elske Livet,

Saa for Dig kun Hjertet banker,

Saa kun Du i mine Tanker

Er den dybe Sammenhæng!

I I.

Skiøndt jeg maa som Blomsten visne, Skiøndt min Haand og Barm maa isne, $\mathrm{Du}$, jeg troer, kan det saa mage, At jeg Døden ei skal smage,

Du betalde Syndens Sold!

I 2.

Ja, jeg troer paa Korsets Gaade, Giør det, Frelser, af din Naade! Staae mig bi, naar Fienden frister! Ræk mig Haand, naar Øiet brister! Siig: vi gaae til $\mathrm{P}$ a r a d is !

2. I. Lad os straks notere afvigelserne mellem originalteksten, trykt $\mathbf{i}$ »Sang-Værk til den danske Kirke« ( I 837), og den version, der er optaget $\mathrm{i} \gg$ Den danske salmebog« ( $\gg 25$. februar I953 autoriseret af Hans Majestæt Kong Frederik IX til brug ved gudstjenesterne i landets kirker $\ll)$. I den officielle version er salmen forkortet med tre strofer. Dette kan forklares med praktiske årsager: tolv strofer er muligvis en upraktisk længde for en salme, der skal bruges ved menighedssangen. Imidlertid er det, som den følgende analyse vil vise, tre strategisk vigtige strofer, der på denne måde er udgået, nemlig stroferne 2-4 incl. Oven i købet er det en forkortelse, der bevirker at tekstsammenhængen forstyrres. Selvom den syngende menighed måske ikke umiddelbart vil lægge mærke til det, er der opstået et logisk »hul« ved sammenkoblingen af strofe I og strofe 5, idet den sidstnævnte strofes spørgsmål i salmebogsversionen er helt umotiveret: at »verden« kroner frelseren med torne har nok sammenhæng med, at frelseren »ville alt opgive for at holde os $\mathrm{i}$ live«, men denne sammenhoeng fremgår netop ikke af salmebogsversionen, som blot postulerer den (eller måske antager den for at være almindelig bekendt?) Samtidig udvisker forkortelsen, som det vil blive vist, en interessant dichotomi 
mellem på den ene side »verden« og på den anden side »jeg«, der $\mathrm{i}$ hvert fald $\mathrm{i}$ originalteksten kun kan være det skrivende digtende jeg og ikke det enkelte syngende medlem af menigheden, i modsætning til, hvad der er tilfældet i salmebogsversionen, som i det mindste tillader, at man foregøgler sig identiteten mellem »jeg « og den syngende enkelte og dermed dette »jeg «'s faktiske omfortolkning til et »vi«.

Også dette sidste kunne forklares ved praktiske årsager, da salmen altså er beregnet til menighedsbrug. Imidlertid vækker det en mistanke om, at forkortelsen kan have haft ideologiske årsager: Grundtvig viste selv, f. eks. med omdigtningerne af »De Levendes Land«, vejen man kunne gå, hvis man ønskede at gøre en grundtvigsk tekst til en regelret grundtvigiansk salme.

2.2 Det er bekendt, at »Hil dig Frelser og Forsoner er en gendigtning af det middelalderlige salmeværk $\gg$ Rythmica oratio ad unum quodlibet membrorum Christi patientis et a cruce pendentis «, men at den version, Grundtvig gendigter i realiteten er en sammenstykning af disjecta membra fra dette salmeværk. Det er ligeledes bekendt, at han i tekstens første halvdel holder sig nogenlunde til originalen, men at han fra strofe 7 og ud gradvist frigør sig fra den (om alt dette se: A. Malling: Dansk salmehistorie) Det er endvidere blevet sagt, at denne salme er et lige typisk udtryk for objektiv som for subjektiv forsoningslære (Niels Møller).

Det vil i det følgende blive søgt påvist, at Grundtvigs tekst i højere grad understreger det subjektive end det objektive aspekt, og at dette kan have sammenhæng med selve den funktion, teksten synes at udfylde ved etableringen af forsoningen.

3. Da Grundtvig omdigtede »De Levendes Land«, der gerne kan betragtes som den grundtvigske kristendomsopfattelses programskrift, erstattede han overalt det personlige pronomen $\gg j e g$ med »vi《 (og dets afledninger). Bortset fra stroferne 5 og 6 er hele $\gg$ Hil dig Frelser og Forsoner « holdt $\mathrm{i} » j$ jeg «-form. En fortolkning kunne derfor tage sit udgangspunkt i denne kendsgerning og undersøge »jeg «ets placering i tekstens økonomi og dets forhold til »verden« og til »os« i str. 5-6. I denne forbindelse kunne man spørge, hvad første strofes udsagn egentlig er: hvad er det for en »rosenkrans« »jeg « har i sinde at vinde om Kristi kors, og hvorfor beder $\gg j e g \ll$ ham om at give »mig « både mod og held dertil? 
3.I. Beder man om mod, må det være fordi man er modløs, beder man om held, må det være fordi man tvivler på sine evner, sin udholdenhed eller eventuelt sin tro, hvilket sidste som det vil vise sig er det mest nærliggende i den givne kontekst. Men strofen fortæller intet om årsagen til modløsheden eller tvivlen, de nærmeste strofer ejheller. Først i strofe I I - tekstens næstsidste - røbes årsagen: jeg ved, at jeg skal dø, og jeg frygter denne død - samtidig med at strofe Io, læst i lyset heraf, antyder, at dødens uundgåelige realitet har kastet salmisten ud i tvivl om »den dybe sammenhæng «. Netop dette peger mod en dobbelthed i det flere gange gentagne »jeg troer «, som ganske er blevet udvisket i salmebogsversionen, til den grad, at salmebogsredaktionen har fundet sig foranlediget til at indføre et meningsløst kolon i originalens strofe 8 (strofe 5 i salmebogen) - Dog jeg tror: af dine vunder .... - hvorved man har gjort salmen til en regelret trosbekendelse og således har forflygtiget (forvansket) tekstens egentlige problematik.

I dette perspektiv kan rosenkransen i en første instans fortolkes som et middel til at genvinde troen, f. eks. gennem bøn (selvom katolske rekvisiter er fremmede for den grundtvigske kristendomsopfattelse, er det ikke helt utænkeligt at associationen til rosen-bedekransen kan have ligget bag valget af netop dette symbol). Denne tolkning støttes af den følgende strofe, hvor »jeg « træder frem for Kristi ansigt, fordi han tror at Kristus er tilstede, og begynder at tilbede ham. På dette sted synes »tror « endnu ikke at have den absolute karakter af uafviselig overbevisning. Der er langt snarere, i overensstemmelse med den fremhævede kontekst, tale om en formodning, som »jeg « gerne vil have bekræftet. Det samme synes at være tilfældet i strofe 8 - »Dog jeg troer, af dine Vunder / Væld udsprang til stort Vidunder. $\ll-$ og i strofe I I $-\gg D u$, jeg troer, kan det saa mage, / At jeg Døden ei skal smage« (man bemærke kommateringen!). Formodningen støttes af den kristne lære, som »jeg « jo imidlertid er kommet i tvivl om, hvorfor han da også logisk henvender sig til denne læres ophavsmand i håb om at få et svar eller at blive befæstet. At det forholder sig således, synes ligeledes at fremgå af strofe 4 , hvor »jeg « ved, at (den historiske) Jesus blev født ved midnatstide, og at han selv valgte korsets skam: denne viden føres netop frem som en første støtte for formodningen, skønt den straks kaster digteren ud i forundring hvorfor gjorde Jesus dette? så stærk var altså hans kærlighed til menneskene! kan dette være muligt? - og den danner en slags bro mel- 
lem formodningen (tvivlen) og sidste strofes afgjorte og overbeviste tro på korsets gåde.

Men vejen til denne tro, eller til genvindelsen af troen, går altså over en konfrontation med Kristi lidelse, som ikke skal forstås men accepteres som forløsningens årsag.

3.2. På dette punkt er originalteksten, i modsætning til salmebogsversionen, klar og utvetydig: denne konfrontation er helt personlig, det er digter-jeg'et der foretager den, og dette jeg placerer sig selv i modsætning til »verden « og de andre. Strofe I fortæller, at verden kroner frelseren med torne, mens jeg derimod ønsker at flette en rosenkrans om hans kors. Det er mig, Kristus betragter med medlidenhed, og det er i mine årer »Floden som kan Klipper vælte« skal ledes ind, for at jeg kan lære at elske livet. Denne inderlige kontakt mellem »jeg《 og frelseren (»du«), som han taler til, understreges kraftigt af syntaksen i den strategisk vigtige strofe 3, hvor kontakten sluttes: »Mig fra Korsets Træ betragter / Du med dyb Medlidenhed (hvorved »modet« og »heldet《 allerede bliver stillet digteren i udsigt, således at han trøstigt kan gå videre!) Det korte skift til »os《i strofe $5^{-}-6$ betoner kun yderligere dette forhold, ikke mindst på baggrund af den omtalte viden, der kommer til udtryk i strofe 4: den kristne lære siger, at Kristus døde for vor skyld, og selvom digteren forundret spørger, hvorfor han gjorde det (når »vi« - verden - har kronet ham med torne), må han dog konstatere, at korsdøden er en historisk kendsgerning og forklare det med, at kærligheden altså her var stærkere end døden (man bemærker udråbstegnet ved udgangen af strofe 6).

Det er erkendelsen af modsætningen mellem en sådan gådefuld og alt opofrende kærlighed og hans egen tvivl, der får digteren til at bede den korsfæstede om at hjælpe ham tilbage til troens rette vej, og som forvandler hans formodning om Kristi nærvær for ham til vished. Det er også den, der sluttelig indgiver ham fortrøstningen om, at Kristus til sin tid vil tage ham ved hånden og føre ham til Paradis.

4. Der er altså tale om en rent subjektiv forsoningsproces. Denne subjektivisme er imidlertid ikke helt så uproblematisk, som det kan synes at fremgå af ovenstående. Vi ser her helt bort fra, hvad Grundtvig eventuelt måtte have »ment « med sin salme, eller hvad der har været hans bevidste intention. Dette er uvedkommende for tekstens 
eget udsagn, Den er nok produceret af Grundtvig, men selve tekstproduktionen har, som man ved fra moderne tekstteori, sin egen problematik, i hvilken det skrivende subjekt snarere er indskrevet eller bliver indskrevet.

4.I. Det synes akkurat at være denne indskrevethed i teksten og dens problematik, der kan aflæses af »Hil dig Frelser og Forsoner «. Det blev hævdet, at »jeg《 placerer sig i modsætning til »verden«. Men det sker i en tekst! »Jeg « er altså en grammatikalsk person i dette ords egentlige betydning (»gramma $=$ »skrift $\ll$ ).

Forholdet mellem »verden«, »os« og »jeg« kommer med andre ord i stand i en skrift i kraft af hvilken »jeg « skiller mig ud fra »verden« og således også bliver $i$ stand til at etablere et »du《-forhold til den frelser og forsoner, som alverden forhåner. Skriftens produktionskilde er her i følge tekstens eget udsagn angsten for døden (en langt senere filosof hævder som bekendt, at det er oplevelsen af den menneskelige væren som en væren-til-døden, der kan løfte subjektet op fra den anonyme »man《-tilværelse og gøre det til et »jeg «). Og det, skriften selv producerer, er overvindelsen af denne angst gennem troen på korsets gåde. Selve produktionsprocessen former sig som en bøn og en tilbedelse, en påkaldelse og en lovsyngelse. Dens resultat bliver en formular: salmen »Hil dig Frelser og Forsoner«.

4.2. Læser vi nu formularen i dette perspektiv, når vi frem til en fortolkning, som muligvis vil forbavse (forarge) elskere af Grundtvigs store salmer (ikke mindst dem, der kun kender dem fra salmebogsversionen), men som har godt hold i formularen, teksten selv. Da viser det sig nemlig, at denne tekst handler om sin egen tilblivelse. Og den rosenkrans, første strofe taler om bliver i anden instans - salmen »Hil dig Frelser og Forsoner«, der er digterens middel til at genvinde troen. En kort parafrase - som skulle være tilladelig, nu da tekstens paradigme er antydet - kan tjene som argument for denne nye videnseffekt.

4.3 Tekstforløbet kan opdeles i tre afsnit, som atter kan underindeles:

I (strofe I-3) Optakt (introduktion)

I. Skriveren træder ind på skriftens scene, forelægger sit fore- 
havende - at lovsynge den korsfæstede - og beder om mod og held dertil.

2-3. Skriveren konfronterer sig med den korsfæstede, tilbeder ham og opnår den inderlige kontakt med ham, der er en forudsætning for, at hans forehavende skal lykkes (»jeg《-»du«).

II (strofe 4-I I ) Lovsyngelsen.

4-6. Kristus er død for vores skyld, selvom dette er uforståeligt. Men det står fast, at han har gjort det, og at det kun kan skyldes hans store kærlighed.

7-8. Denne erkendelse - og denne gåde - vækker skriverens ruelse: hvordan kan han være hård og uren, og tvivle, når Kristus også er død for ham?

9-10. Skriveren beder - i en direkte anråbelse - Kristus om at hjælpe ham personligt til igen at elske livet, gennem korsgåden, og forstå livets sammenhæng i Kristus.

I I. Fortrøstningen til frelserens hjælp kommer til udtryk. Hvad han i strofe 6 forundrede sig over - at Kristus døde i vort sted - er han nu overbevist om. Derfor er hans personlige død ikke længer noget problem.

III (strofe I 2) Skriverens forehavende er nu lykkedes. Han har, med frelserens hjælp, lovsunget den korsfæstede og gennem lovsangen - teksten, som er blevet produceret - forstået korsets gåde. Fortrøstningsfuldt modtager han nåden. Hans formodning i optakten - Jeg tror, du er tilstede«, »Du er dog miskundelig« - er blevet til overbevist tro: »Ja, jeg troer paa Korsets Gaade«.

5. Hele tekstens mellemstykke er med andre ord en parafrase over $\gg$ jeg tror du er til stede« og at »du er dog miskundelig«. Eller rettere: det er en »tilskrivning « af denne tilstedeværelse og dermed en tilskrivning af Troens rare klenodie. Men er al autentisk salmedigtning ikke det? 